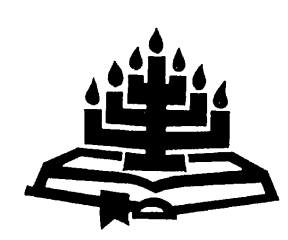

\title{
Insufficientia? In gesprek met die Reformatoriese tradisie en M.A. Kruger oor die (on-)genoegsaamheid van die Godsopenbaring in die skepping, onderhouding en regering
}

\author{
J.H. van Wyk \\ Navorser: Skool vir Kerkwetenskappe \\ Potchefstroomse Universiteit vir $\mathrm{CHO}$ \\ POTCHEFSTROOM \\ Epos: amievw@intekom.co.za
}

\begin{abstract}
Insufficientia? In discussion with the Reformed tradition and M.A. Kruger on the (in-)suffiency of God's revelation in creation, preservation and government
\end{abstract}

In this article the author investigates the issue of the meaning and suffiency of the revelation in creation. Reformed churches confess in Article 2 of the Belgic Confession that we know God by "two means", first by "the creation, preservation and government of the universe", and secondly, "more clearly and fully", by His holy and divine Word. The question considered in this article is the following: Is God's revelation in creation sufficient for man to obtain saving faith? Regarding this issue the author reflects on answers given by some influential theologians, deals with confessional and theological considerations, and ends with a description and assessment of the views of M.A. Kruger. The article concludes with a recapitulation of the ideas explored.

Opsomming

Insufficientia? In gesprek met die Reformatoriese tradisie en M.A. Kruger oor die (on-)genoegsaamheid van die Godsopenbaring in die skepping, onderhouding en regering

In hierdie artikel ondersoek die outeur die vraag na die betekenis en genoegsaamheid van die skeppingsopenbaring. Gereformeerde kerke bely in Artikel 2 van die Nederlandse Geloofsbelydenis (NGB) dat daar "twee middele" is om God te ken, naamlik deur middel van 
die skepping, onderhouding en regering, én deur sy Goddelike Woord, wat "nog duideliker en meer volkome" is. Die vraag wat in hierdie artikel ondersoek word, is die volgende: Is die skeppingsopenbaring voldoende sodat iemand daaruit saligmakende kennis kan opdoen? Die skrywer ondersoek in hierdie verband die antwoorde van 'n aantal invloedryke teoloë, bestee daarna aandag aan konfessionele en teologiese oorwegings, om daarna die standpunt van M.A. Kruger te behandel en te evalueer. Uiteindelik word enkele samevattende opmerkings gemaak.

\section{Probleemstelling}

M.A. Kruger het met sy proefskrif oor Romeine 1-4 (Kruger, 1983), sy voordrag tydens die Calvyn-kongres (Kruger, 2000a) en sy Romeinekommentaar (Kruger, 2000b) behoorlik 'n knuppel in die teologiese hoenderhok gegooi (vgl. ook Kruger, 1985:130-147; 1988:81-97; 1993: 583-602). Sy standpunt oor die reikwydte van die skeppingsopenbaring het uiteindelik daartoe gelei dat die Kuratorium van die GKSA bevind het dat "die standpunt van prof. Kruger oor die vraag of 'n mens deur die openbaring in die natuur tot saligmakende geloof kan kom, teenoor die Gereformeerde Belydenisskrifte staan" en gevolglik is hy versoek om sy standpunt óf te verswyg óf sinodaal te laat toets (Notule Kuratorium, 1998, art.17).1 Kruger het daarna in appèl gegaan na die Nasionale Sinode van die GKSA, maar sy appèl is nie gehandhaaf nie (Acta GKSA, 2000:47-62). Die Kuratorium het in 2001 na voortgaande gesprekke en onderhandelings (waarop tans nie nader ingegaan word nie) met Kruger 'n ooreenkoms bereik en die klag (voorwaardelik) gestop en is "die problematiek na die Senaat verwys vir 'n diepgaande studie". Hiermee is die saak voorlopig van die tafel af tot tyd en wyl die Kuratorium "weer verslag ontvang van die resultaat van die studie" (Notule Kuratorium, 2001, art. 12.3). 2 Hierdie artikel vorm deel van hierdie navorsingsprojek.

Die vraag is: waaroor gaan hierdie problematiek?

Die probleemstelling gaan, soos genoem, oor die reikwydte van die skeppingsopenbaring (soms ook "algemene openbaring" genoem). ${ }^{3}$ Is dit

Daar word in hierdie artikel nie ingegaan op die ontstaansgeskiedenis van die besluit en die hele debat wat daarop gevolg het nie.

2 Die Nasionale Sinode van die GKSA 2003 het hieroor soos volg besluit: "Hierdie gesprek word nie verder gevoer nie. Prof M.A. Kruger onderneem om nie sy standpunt propagandisties te verkondig nie. Die Kuratore ... onderneem [derhalwe] om die geformuleerde klagte teen [p]rof. Kruger, wat nog nie in behandeling geneem is nie, te stop" (Notule GKSA 2003, art. 122) (Die Handelinge 2003 is tans nog in druk.)

3 Kruger (1983:357-358) wys die begrippe "algemene openbaring" en "besondere openbaring" af. So ook Van der Walt (1999:93-95). 
moontlik dat iemand uit hierdie openbaring saligmakende kennis kan opdoen? Gee Romeine 1 aanleiding tot so 'n standpunt of weerspreek dit juis so 'n benadering? Word ware kennis van God dan nie uitsluitlik uit die Skrifopenbaring opgedoen nie, en is geloof in Jesus Christus dan nie die enigste weg tot saligheid nie?

Kruger som sy eie standpunt soos volg op:

My eksegetiese konklusie ten opsigte van wat Romeine leer oor openbaring ... (is) ... dat mense wat nooit die Skrif leer ken het nie, tog gered kan word deurdat die Heilige Gees hulle lei om positief te reageer op God se openbaring in die skepping, onderhouding en regering van alle dinge. Dit is so aanvaar tot by die Sinode van Dordt en Calvyn is baie eksplisiet daaroor (Institusie 1.5.1) (Brief M.A. Kruger, 20-02-2002).

Reeds in 1983 kom Kruger (1983:355) tot die volgende konklusie:

Hierdie kennis [van God uit die skepping ens.] moet nie maar afgemaak word as 'n nie-saligmakende kennis nie. Dit was voldoende om tot 'n herstelde verhouding tot God te kom.

Anders gesê (weer eens in sy eie woorde):

People can come to a saving faith in God through the revelation in creation, preservation and government of the universe. (People) if they come to a true knowledge of themselves and as poor in spirit throw themselves in full trust upon the God who speaks to them and for their benefit in this language, they will be saved. This is what Romans teaches. Scripture does not speak of the insuffiency of the revelation in creation (Kruger, 2000:12-13).

In hierdie artikel word eerstens aandag bestee aan 'n aantal dogmatiese perspektiewe van invloedryke teoloë, daarna word konfessionele gesigspunte uitgelig, vervolgens enkele teologiese oorwegings deurgegee en ten slotte met M.A. Kruger in debat getree.

\section{Dogmatiese perspektiewe}

Wanneer die dogmatiese perspektiewe bespreek word, kan'n paar standpunte duidelik onderskei word, byvoorbeeld:

- Die Rooms-Katolieke benadering met sy dualisme van natuurlike en bonatuurlike teologie. In hierdie benadering word aan die natuurlike teologie (Godsbewyse) 'n belangrike plek toegeken (Tomas van Aquino). Tog word die insufficientia van die natuurlike teologie duidelik erken (Tomas van Aquino, 1989:26-29; vgl. Bavinck, 1928: 283-284). 
- Die Reformatoriese benadering waar aan die algemene of natuuropenbaring wel 'n duidelike, maar gekwalifiseerde plek toegeken word: kennis van God, voldoende om alle verontskuldiging weg te neem, maar onvoldoende tot saligheid (Calvyn, $H$. Bavinck, Berkouwer, Polman ens.) (J.H. Bavinck het hierdie standpunt probeer nuanseer.)

- Die Dialektiese Teologie van Karl Barth met 'n skerp afwysing van alle natuurlike teologie/openbaring en 'n sterk Christosentriese benadering van die openbaring (Barth, Beker \& Hasselaar).

- Die nuwe benadering waar 'n baie hoë waardering aan die natuuropenbaring toegeken word (Pannenberg) en selfs 'n kennis tot verlossing aanvaar word (M.A. Kruger).

Vervolgens word enkele belangrike verteenwoordigers van hierdie standpunte aan die woord gestel.

\subsection{J. Calvyn: die sonde verblind}

Wanneer ons na die standpunt van Calvyn kyk, is dit baie belangrik om hom nie selektief aan te haal nie, maar dat telkens na die wyer konteks van sy uitsprake gekyk word.

Calvyn oordeel dat die doel van die openbaring van God in die natuur "is dat toetrede tot geluksaligheid nie by voorbaat vir enigiemand geslote sou wees nie" (Inst. 1.5.1). Sodanige kennis behoort "ons nie alleen tot aanbidding van God te wek nie, maar dit moet ons ook tot hoop op 'n toekomstige lewe aanwakker en verhef" (Inst. 1.5.10). Deur die deugde van God in sy werke raak te sien, "word die hele mensdom uitgenooi en gelok om Hom te eer en deur hulle kennis tot waaragtige en volle geluksaligheid te kom" (Inst. 1.5.10). Dit is sterk taal wat Calvyn hier gebruik. Tog kwalifiseer hy hierdie siening weer as hy opmerk dat die suiwere waarheid van God deur die mens se ydelheid en dwaasheid bederf word (Inst. 1.5.11) en dat daar dus méér nodig is. "As mense slegs deur die natuur onderrig is, het hy geen sekerheid, geen vastheid en geen onderskeid om aan vas te hou nie" (Inst. 1.5.12). Daarom moet daar 'n "beter hulpmiddel" bykom, naamlik die Woord, sodat God daardeur "tot ons heil" aan ons bekend kan word (Inst. 1.6.1). Ons het die bril van die Skrif en die oog van die geloof nodig. Om die Skrif as Woord van God te aanvaar en te verstaan het ons weer die getuienis van die Heilige Gees nodig (Inst. 1.7.4). By Calvyn voltrek hom dus een groot ontsluitingsproses: die Godsopenbaring in die natuur is daar, maar dit moet ontsluit word deur die Godsopenbaring in die Skrif; die Godsopenbaring in die Skrif is daar, maar ook dit moet ontsluit word deur die verligting deur die Gees. 
Calvyn se teologie is soos ' $n$ spinneweb: as aan een draadjie daarvan geraak word, beweeg die hele web. Sy openbaringsleer is ten nouste met sy mensleer en sondeleer verbind, en dié weer met sy Christologie en Pneumatologie. Die sonde het die mens radikaal aangetas, die mens is deur sy misdade dóód (Ef. 2:15) (Inst. 2.5.19). Dit is só dat die beeld van God vanweë die sonde wel nie volkome tot niet gemaak en uitgewis is nie; tog is dit so verdorwe dat die oorblyfsels daarvan verskriklik misvorm is (Inst. 1.15.4) (vgl. verder Van Wyk, 1993:10-14). Calvyn kan natuurlik opmerk dat ons nie moet dink dat die mens se natuur ten volle bedorwe is nie, want daar is nog die genade van God, maar dan voeg hy onmiddellik by: "nie om die bedorwenheid te suiwer nie, maar om dit in bedwang te hou" (Inst. 2.3.3). In sy behandeling van die Christologie merk hy op dat die kennis van God ons Skepper "vir ons nutteloos sou gewees het as dit nie was dat die geloof wat God die Vader in Christus vir ons aanbied, vir ons beskikbaar was nie" (Inst. 2.6.1). Maar ook hierdie Christologiese kennis benodig pneumatologiese aanvulling: "Alles wat Christus vir die saligheid van die mensdom gely en gedoen het, is vir ons nutteloos en van geen waarde nie solank ons sonder Hom is en solank ons van Hom geskei is" - iets wat slegs deur die "verborge werking van die Gees" voltrek kan word (Inst. 3.1.1).

\subsection{H. Bavinck: Christus ontbreek}

Bavinck staan wesentlik binne die Calvynse tradisie. Hy wys onder andere daarop dat die algemene openbaring te alle tye in die Christelike teologie aangeneem en verdedig is (Bavinck, 1928:282). Die mens is immers wesentlik 'n religieuse wese (Bavinck, 1928:279). "Deze revelatio generalis is echter om verschillende redenen onvoldoende. Ook hierin zijn alle Christelijke theologen eenstemmig" (Bavinck, 1928:283). Bavinck vervolg dan dat "over de insufficientia der algemene openbaring kan er haast geen twijfel bestaan" (Bavinck, 1928:284) en dan noem hy 'n aantal redes daarvoor op:

- die algemene openbaring ken nie die persoon van Christus en weet daarom nie van genade en vergewing nie;

- die kennis van die algemene openbaring is gering, onvoldoende en onseker en met dwaling vermeng;

- geen enkele volk was ooit met die religio naturalis tevrede nie (Bavinck, 1928:284-286).

Daarmee wil Bavinck nie die groot betekenis van die algemene openbaring vir heidenvolke (en vir die Christendom) ontken nie. By die heidene is immers "elemente van waarheid" te vind, van die ware, die 
skone en die goeie (Bavinck, 1928:286-291). Hy gaan selfs so ver om die volgende (omstrede) opmerking te maak:

Daarom staat het Christendom niet uitsluitend antithetisch tegen het heidendom over; het is er ook de vervulling van. Het Christendom is de ware, maar daarom ook de hoogste en zuiverste religie, het is de waarheid van alle godsdiensten (Bavinck, 1928:291).

Ander gereformeerde dogmatici het in die voetspoor van Bavinck voortbeweeg: 'n ja vir algemene openbaring en 'n nee vir natuurlike teologie (Polman, 1949:80-86; Heyns, 1978:7-11; Spykman, 1992:168170; Dekker, 1996:93-123, laasgenoemde met klem daarop dat die openbarende God die drie-enige God is); 'n aanvaarding van die noodsaak van die natuuropenbaring, maar ook 'n erkenning daarvan dat dit onvoldoende (tot saligheid) is. "Kennis van God zonder erkenning van God is in de Bijbel geen echte kennis van God!" (Van Genderen \& Velema, 1992:56). Vanweë die sonde vind daar verdringing en vervanging van die Godskennis plaas. Wentsel (1982:51-52) wys daarop dat die effek van die natuuropenbaring op die heidenvolke in die Skrif deurgaans negatief is: hulle verval in veelgodedom en immoraliteite. In sy bespreking van ons tema (Wentsel, 1982:46-65) voer Wentsel 'n interessante onderskeiding in:

Van de kant van God is de algemene openbaring genoegzaam om God te kennen. Maar van de kant van de mens is deze ongenoegzaam tot de echte kennis van God en genoegzaam om hem te veroordelen (Wentsel, 1982:60).

Deze openbaring is van Gods kant uit gezien - Gezien deze onmacht [van de mens] is deze openbaring onvoldoende om God te kennen en daarom niet toereikend tot zaligheid (Wentsel, 1982:62).

(Vir 'n uitgebreide diskussie vgl. Wentsel, 1987:153-202.)

\subsection{Karl Barth: "Nein!"}

Onder indruk van die geweldige suigkrag van 'n natuurlike teologie soos dit voor en tydens die Tweede Wêreldoorlog (1939-1945) in Duitsland onder "Duitse Christene" ontwikkel het, het Karl Barth 'n sterk Christosentriese openbaringsleer ontwikkel (vgl. Polman, z.j.:159 e.v.; Berkouwer, 1951:14-26). Openbaring is nie maar openbaring van 'n godheid nie, maar is die openbaring van die enige ware God in Jesus Christus alleen. Vir Barth is daar maar een openbaring en dit is die openbaring in Jesus Christus. 'n Mens kan nie naas die openbaring in Christus ook nog 'n ander openbaring (die geskiedenis of Hitler!) hê nie. Openbaring is die soewereine Godsopenbaring van versoening waardeur alle menslike godsdiens onder kritiek geplaas word. Die waar- 
heidsvraag kan nooit van die heilsvraag losgemaak word nie. Vanuit hierdie sterk Christosentriese benadering het Barth gefulmineer teen die gedagte van 'n aanknopingspunt in die mens en wat hy "' $n$ dubbele boekhouding" genoem het, en het hy sy ondubbelsinnige "Nein!" teenoor Brunner se gedagte van 'n aanknopingspunt uitgespreek. Vir Barth bestaan daar nie 'n twee-bronne-teorie nie, Skrif-plus-natuur, want, sê hy, so 'n benadering verskil niks van die Katolieke Skrif-plus-tradisie-teorie nie. In sy Die Kirchliche Dogmatik 1.2 (Barth, 1960a:304-397) argumenteer hy dat die Godsopenbaring die opheffing van religie beteken. Menslike religie kan slegs as ongeloof getipeer word, as afgodery en selfregverdiging waardeur die mens die openbaring weerspreek. (Later sou Barth in Die Kirchliche Dogmatik 4.1 [Barth, 1960b] op positiewe elemente wys wat die openbaring in Christus vir die wêreld inhou.)

Dit is duidelik dat Barth op hierdie punt nóg Calvyn nóg NGB 2 kon byval (Dekker, 1996:110).

In Nederland het hierdie Christosentriese benadering van Barth sterk byval gevind by die teoloë Beker en Hasselaar (1978:10-50; vgl. ook Berkhof, 1990:41-81).

De geschiedenis zegt ons, dat de natuurlijke theologie zich in de dogmatiek wel bescheiden opstelt, maar in het corpus christianum haar rol speelde als de ongekroonde koningin van het westerse denken en de westerse politiek (Beker \& Hasselaar, 1978:15).

Hulle oordeel dat die grondfout van die theologia naturalis daarin geleë is dat dit op geen manier oor die drie-enige God kan spreek nie, en daarsonder kan God nie verstaan word nie (Beker \& Hasselaar, 1978: 22).

In Suid-Afrika het veral teoloë uit die NHKA aansluiting by Barth se Christosentriese benadering gevind, soos onder andere blyk uit die proefskrif van D.J.C. van Wyk (1973:75-85).4 D.J.C. van Wyk is van oordeel dat ons in die teologie van Calvyn met teenstrydige uitsprake te doen het en dat die (Calvynse) idee dat 'n mens buite Jesus Christus om ware Godskennis kan opdoen, onversoenbaar is met die res van Calvyn se teologie (Van Wyk, 1973:50-55). Van Wyk (1973:55-59) laat hom ook krities uit oor die formulering van NGB artikel 2 ("twee middele") en hy stem saam met Barth se opmerking dat die NGB 2 'n oorblyfsel is van die Roomse twee-bronneleer. Vir Van Wyk is daar net één bron en dit is

$4 \quad$ Dit val op dat die standpunt van D.J.C. van Wyk (oor die skeppingsopenbaring en die interpretasie van Romeine) diametraal staan teenoor dié van M.A. Kruger, waaraan ons later aandag bestee. 
die Skrif. 5 Hy wys ook die standpunte van sogenaamde Neo-Calviniste (Berkouwer en Polman) af (Van Wyk, 1973:85-92). Die heidene doen kennis van God (en van waarheid, geregtigheid ens.) op - nié vanweë die selfbeskikkende vermoë van die mens nie, maar vanweë die getuienis van Israel en die kerk (Van Wyk, 1973:119-131, 141). D.J.C. van Wyk interpreteer Romeine sodanig dat die menslike verstand God nie kan ken nie (Gal. 1:12; 2 Kor. 12:1-4; Ef. 3:3); die mens beskik eenvoudig nie oor die eienskap om Gods wysheid te ken nie (Van Wyk, 1973:138-139). "'n Skeppingsopenbaring op grond van Rom. 1:20 moet afgewys word" (Van Wyk, 1973:143). Ook ten opsigte van Romeine 2:14-15, die locus classicus vir die natuurlike teologie, geld dat die natuurlike mens die dinge van die Gees van God nie aanneem nie (1 Kor. 2:14); die heidene kén God nie ((1 Kor. 1:2 e.v.; Gal. 4:8; 1 Tess. 4:5; Ef. 4:17-20) (Van Wyk, 1973:144-145). "Die apostel poog beslis nie hier om 'n nie-Christelike heilsweg oop te maak en oop te hou nie" (Van Wyk, 1973: 146). Van Wyk distansieer hom sover moontlik van die skeppingsopenbaring: "Die algemene openbaring is 'n produk van die Griekse filosofie wat met die Bybelse verkondiging niks te make het nie" (Van Wyk, 1973:148). "Daar is in die Bybelse denke nie plek vir 'n algemene openbaring nie. Kennis van God is nie vir alle mense moontlik nie" (Van Wyk, 1973:152).

\subsection{J.H. Bavinck: Die Gees werk waar Hy wil}

Die gereformeede missioloog J.H. Bavinck sou, via Kraemer, wat sterk aansluiting by die benadering van Barth gevind het, ook in 'n beperkte sin aansluiting by Barth vind, terwyl hy ook bepaalde korreksies op die tradisionele beskouing aangebring het (Bavinck, 1949:118-129; 1954: 136-146; vgl. verder die deeglike proefskrif van Visser, 1999:114-162). Uitgaande van die werklikheid van die algemene openbaring, merk Bavinck op dat hierdie openbaring die mens nie bereik buite die werk van die Heilige Gees om nie (Visser, 1999:123). Hy neem afskeid van allerlei aspekte van die Neo-Calvinistiese optimisme ten aansien van aktuele heilskennis wat die algemene openbaring sou kon oplewer (Visser, 1999:126). Hy handhaaf die prinsipiële eenheid tussen die algemene en besondere openbaring, maar ook hulle wesentlike onderskeid: by die algemene openbaring ontbreek die moontlikheid om tot ware kennis van God te kom; dit besit nie die krag (dunamis) tot saligheid nie (Rom. 1:16); dít is alleen in die evangelie van Jesus Christus te vind (Visser, 1999:127). Uit die Skrif is egter duidelik dat die met die volkskerkgedagte van die NHKA en die (vroeëre) artikel 3 van die Kerkwet. Rus hierdie gedagtes op die Skrif en Christus alleen of kom dit op uit "algemene openbaring"? 
sondige mens hierdie openbaring van God "verdring" en "vervang". Hy distansieer hom skerper as die tradisionele gereformeerde teologie van die gedagte dat daar in die mens 'n substansiële vermoë aanwesig is om die openbaring van God op te vang en beklemtoon die eksistensiële tweegesprek tussen God en mens - genuanseerder as Barth (wat slegs 'n onoorbrugbare kloof beklemtoon) (Visser, 1999:160-161). Bavinck (1954:145) spreek ook eerder van 'n aangrypingspunt as aanknopingspunt.

Die Gees van God werk egter waar en soos Hy wil. Vandaar Bavinck se opmerking: "Op het zendingsveld staan wij heden ten dage telkens voor het verrassende feit, dat God door dromen of gezichten mensen op de weg leidt naar het evangelie" (Visser, 1999:128). 6

Dit is trouens opmerklik dat ons probleemstelling juis telkens vanuit 'n sendingkonteks gestel word, soos byvoorbeeld die geval is by J.H. Bavinck. ${ }^{7}$ Insiggewend is daarom ook die volgende opmerking van die missioloog J. du Preez (2000:10):

Soos God die verbondskinders van Christen-ouers kan red sonder dat hulle van Jesus gehoor het omdat hulle jonk gesterwe het, kan Hy ook mense van ander gelowe (oud en jonk) red wat nooit van Christus gehoor het nie. Maar dit geskied alleen op grond van Christus se genoegsame kruisoffer vir die hele wêreld, omdat daar geen ander naam is waardeur ons gered kan word nie. 8

\subsection{W. Pannenberg: Offenbarung als Geschichte}

Afgesien van Pannenberg se groot poging om rasionele en intellektuele integriteit in die die beoefening van teologie in te bou, het hy hom veral verset teen Bultmann se onhistoriese en eksistensiale teologie, maar daarmee saam ook teen Barth se - vir sy gevoel - eensydige Woordteologie. Vandaar Pannenberg se herwaardering van die betekenis van geskiedenis en van Offenbarung als Geschichte (Pannenberg, 1988:230257; vgl. 63-118 asook Pannenberg, 1993.). Vir Pannenberg is open-

6 Vgl. in hierdie verband ook die interessante opmerking van Van Ruler (1978:150): "De heiden komt niet pas met de waarachtige en levende God in aanraking, wanneer een zendeling met het evangelie van Jezus Christus tot hem komt. Hij was reeds lang met Hem in aanraking. Zijn gehele bestaan is een ontmoeting met de levende God."

7 Dit is belangrik om in gedagte te hou dat M.A. Kruger ook vir 'n lang periode van sy lewe 'n sendeling was.

8 Vgl. ook Du Preez se verklarende opvolgbrief in Die Kerkbode van 21 April 2000. Vir 'n verbondsmatige benadering van ons probleemstelling, vergelyk Wielenga (1998:219233). 
baring 'n openbare en universeel historiese gebeurtenis wat as 'n daad van God geïnterpreteer kan word. Maar die sin van geskiedenis kan (in sy totaliteit) slegs vanuit die einde van die geskiedenis goed verstaan word. Die einde weer word prolepties onthul vanuit dit wat reeds in die geskiedenis gebeur het, naamlik die (werklike) opstanding van Jesus Christus in die tyd. Teologie is op geskiedenis gebaseer, op histories kontroleerbare feite, in besonder die opstanding van Jesus. Filosowe (Hume en Lessing) en teoloë (Troeltsch) wat met die prinsipe van analogie werk en die liggaamlike opstanding by voorbaat uitsluit, laat dus (foutiewelik) toe dat hulle voorveronderstellings hulle konklusies vooraf bepaal. Geskiedenis is vir Pannenberg dus eskatologies en Christologies gestempel.

\subsection{Ekskurs: H.G. Stoker: Wysbegeerte van die skeppingsidee}

Dit is algemeen bekend dat die idee van van die Godsopenbaring in die Christelike filosofie 'n baie belangrike rol speel. So het H. Bavinck 'n Wysbegeerte van die openbaringsidee, D.H.T. Vollenhoven en $\mathrm{H}$. Dooyeweerd 'n Wysbegeerte van die wetsidee en H.G. Stoker (1970: 202-330) 'n Wysbegeerte van die skeppingsidee ontwikkel. Volgens Stoker (1970:242-243) is die skeppingsidee die mees omvattende grondidee in die Christelike wysbegeerte. In hierdie benadering word sodoende 'n swaar aksent gelê op die skeppingsidee, al word (formeel) erkenning verleen aan die gesag van die Skrifopenbaring (Stoker, 1970: $214,244)$. Die vraag is egter of Stoker hom in die uitwerking van hierdie skeppingsidee genoegsaam kon vrywaar teen die gevaar van 'n natuurlike (en fenomenologiese) filosofie, as gevolg waarvan die Skrifopenbaring deur die skeppingsopenbaring onder druk geplaas is (vir 'n kritiese evaluering hiervan, vgl. Van Wyk, 2001:188-213). Om 'n enkele voorbeeld te noem, kan verwys word na die rol wat die skeppingsordeninge in hierdie verband speel. Vir Stoker is die volk, saam met die huwelik, die gesin, die staat en die kerk, een van die primêre samelewingskringe (skeppingsordeninge), 'n standpunt wat in die lig van die Skrifgegewens oor die eenheid van die mensdom, nie gehandhaaf kan word. Die mensheidsgeskiedenis begin nie met volke nie, maar met twee individuele mense. So was Stoker se formele erkenning van die Skrifopenbaring onvoldoende om hom teen die volksabsolutisme van apartheid te beskerm.

In hierdie verband het die Christelike filosofie van B.J. van der Walt 'n belangrike korreksie op dié van Stoker aangebring. Ook hy onderskei tussen skeppings- en Woordopenbaring, hoewel hy sterk klem lê op die eenheid van die openbaring (Van der Walt, 1989:74-96; 1992:52-68; 1994:56-89; 1999:87-120). Hoewel almal nie met Van der Walt sal saamstem dat "nie een van God se openbaringsvorme belangriker as 
die ander is nie" (Van der Walt, 1999:95) en dat die Skrif- en skeppingsopenbaring "ewe gesagvol" en "ewe waar" is (Van der Walt, 1999:91), ${ }^{9}$ moet tog opgemerk word dat hy, waarskynlik vanweë sy sterk teologiese agtergrond en onderbou, méér as Stoker aan die Woordopenbaring reg laat geskied. So kan hy (Van der Walt, 1994:216) by geleentheid prioriteit verleen aan die Woordopenbaring. Dit blyk ook uit sy kritiese opstelling teenoor die volksfilosofie van apartheid (Van der Walt, 1995). Verder is dit myns insiens baie belangrik dat Van der Walt (1994:94-99, 452-454) boustene aandra vir wat 'n Wysbegeerte van die koninkryk genoem sou kon word.

Vervolgens word enkele konfessionele perspektiewe kortliks toegelig.

\section{Konfessionele perspektiewe}

Wat die Gereformeerde Konfessies betref, spits die hele debat hom veral toe op 'n interpretasie van die Nederlandse Geloofsbelydenis artikel 2 (NGB 2). Daar is wel ook ander gedeeltes waar ons vraagstelling aangeraak word, soos byvoorbeeld NGB artikel 14 waar bely word dat die mens vanweë sy sonde "al sy voortreflike gawes wat hy van God ontvang het, verloor het, en (dat) hy niks anders daarvan oorgehou het nie as slegs klein oorblyfsels, wat egter genoegsaam is om hom alle verontskuldiging te ontneem." Ook in die Dordtse Leerreëls 3/4:1.4 word hierdie vraagstuk betrek: "Vir die mens is dit egter onmoontlik om deur hierdie lig van die natuur tot die saligmakende kennis van God te kom en hom tot God te bekeer." Die natuurlike Godskennis word deur die mens op verskillende maniere "verduister" en hy "bedek dit in ongeregtigheid"; "omdat hy dit doen, is daar vir hom geen verontskuldiging voor God nie" (vgl. ook Heidelbergse Kategismus 2:3 en 6:19).

Daar bestaan onder teoloë redelike eenstemmigheid daaroor dat hierdie motief van "oorblyfsels" nie bedoel is - en ook nie so gesien behoort te word nie - om die totale korrupsie van die mens deur die sonde te relativeer nie, maar juis om dit te aksentueer (Berkouwer, 1957:132; Jonker, 1994:63).

Vir ons doel is veral NGB 2 van besondere belang, wat in die Latynse teks soos volg lui: ... Rom 1.20. Quae omnia ad convincendos et inexcusabiles reddendos homines sufficiunt (Bakhuizen van den Brink, 1940:61). Dit val egter dadelik op dat wanneer uiteensettings van hierdie artikel nagegaan word (bv. Polman, z.j.:144-159; Heyns, 1988:62-78), grotendeels teruggeval word op wat Calvyn asook die Reformatoriese

9 Vgl. ook die kritiek van Malan (1994:152-154) dat die solus Christus onderbeklemtoon word. 
tradisie hieroor te sê gehad het. Die Belydenis word dus grotendeels in terme van die teologie van Calvyn verstaan en uitgelê. Die konklusie is telkens duidelik: Godskennis uit die natuur is moontlik; dit word egter egter telkens deur die mens afgewys, kan dus nie tot saligheid lei nie, maar ontneem die mens nogtans alle verontskuldiging (Polman, z.j.:147150; Berkouwer, 1951: 220-234; Heyns, 1988:70).

'n Belangrike gesigspunt wat deur navorsers beklemtoon word, is wie die subjek van die geloofsbelydenis is, die "ons" wat hierdie belydenis uitspreek (Polman, z.j.:158; Berkouwer, 1951:228; Heyns, 1988:67-68). Die NGB is nie 'n neutrale nie, maar 'n gelóófsbelydenis, wat deur die kérk, deur gelówiges dus, uitgespreek en bely word; mense dus wat van die staanspoor af weet hoe hulle na die natuur, die geskiedenis, die volkewêreld en hulle eie gewete moet kyk, naamlik deur die bril van die Skrif en die bril van die evangelie van genade. Trouens, dit is vir hulle onmoontlik om anders na dinge te kyk as deur die bril van die Skrif waarvan die evangelie die sentrum is.

Berkouwer (1951:231) spreek die mening uit dat die tyd miskien nie meer ver is nie dat die betekenis van NGB 2 opnuut waardeer sal word nié as 'n terugval in natuurlike teologie nie, maar as 'n belydenis van die grootheid en goedheid van die God van die openbaring. Hierdie nuwe belangstelling mag egter nie as 'n twee-bronneteorie gesien en gehanteer word nie - Skrif en tradisie, Skrif en natuur, Skrif en geskiedenis - asof die Godsopenbaring op twee gelykwaardige bronne sou rus (Berkouwer, 1951:233).

Die standpunt dat die skeppingsopenbaring kragtig genoeg en voldoende is om mense tot saligmakende kennis te oortuig, kan moeilik uit artikel 2 in die NGB asook uit die teologie van Calvyn afgelei word. 'n Korrekte verstaan van NGB 2 berus in 'n groot mate op 'n juiste verstaan van die teologie van Calvyn, wat op sy beurt weer gebaseer is op 'n regte interpretasie van Romeine 1-2.

\section{Teologiese oorwegings}

Dit behoort uit die voorafgaande gegewens duidelik te word dat ons probleemstelling in 'n baie groot mate 'n eksegetiese vraagstelling is. Die groot vraag is hoe ons daardie Skrifgegewens interpreteer wat duidelik wys in die rigting van 'n natuurlike Godskennis, soos bv. Johannes 1:4, 5, 9, Handelinge 14:15-17; Handelinge 17:26-27; Romeine 1:19-20 en Romeine 2:14-15. Hierby kan ook gedeeltes van die Ou Testament gevoeg word, soos byvoorbeeld die bekende natuurpsalms $(8,19,104)$ of ook dele uit Job (38-41). Die vraag is eenvoudig: hoe verreikend is hierdie Godsopenbaring? Dui dit net op 'n vae kennis van God of dui dit 
ook op kennis van die wáre (drie-enige) God? Bestaan daar so iets soos 'n "vae kennis van God"? Skerper: handel God nie onbillik teenoor die mens as Hy van hom iets verwag (ware Godskennis) wat die mens in elk geval nie deur middel van die natuur kan bereik nie?

Dit is uit die Skrif self onweerspreeklik duidelik dat God Hom ook aan nie-gelowiges (heidene) op 'n bepaalde wyse openbaar. Hier kan onder meer aan die volgende voorbeelde gedink word:

- Melgisedek, koning van Salem en priester van God (Gen. 14:18-20)

- Abimelek, koning van Gerar (Gen. 20:6)

- Farao, koning van Egipte (Gen. 41:28)

- Jetro, priester van Midian en skoonvader van Moses (Eks. 2:16)

- Bileam, seun van Beor en Oosterse waarsêer (Num. 22 e.v.)

- Die weduwee van Sarfat (1 Kor.17:7-24)

- Kores, die gesalfde van die Here (Jes. 45:1)

- Nebukadnesar, koning van Babel (Dan. 4)

- Die heidennasies wat die Here God eer (Mal. 1:11)

- Die wyse manne uit die Ooste (Matt. 2:2)

- Die filosowe in Atene (Hand. 17:23)

Uit hierdie voorbeelde kan egter nie afgelei word dat hierdie soort Godsopenbaring noodwendig heilsbetekenis gehad het nie, hoewel dit soms wel op heil uitgeloop het, soos in die geval van die wyse manne wat (langs die weg van skeppingsopenbaring en Skrifopenbaring) gesoek en uiteindelik die Verlosser gevind het.

Bostaande gegewens maak duidelik dat God deur sy Gees met mense kommunikeer soos en wanneer Hy wil. Ons probleemstelling gaan egter nie oor die vraag wat God kán doen nie, maar wat Hy wíl doen en wat Hy reeds gedoen het. En dan word duidelik dat sy openbaring in Christus 'n besondere hoogtepunt en finaliteit bereik (Heb. 1:1-2).

'n Verdere opmerklike verskynsel in die Skrif is die verwysing daarna dat selfs ongelowiges tot die Here gebid het en dat Hy hulle gebede verhoor het (Jona 1:14; vgl. Ps. 107:28). (Calvyn verwys ook hierna, Inst. 3.20.15.) Dit wil voorkom of daar in die Skrif self meer soepelheid ten opsigte van die Godsleer aanwesig is as wat dikwels in die (veral skolastieke) dogmatiek aanwesig is. 
Daar is in die Skrif egter ook gegewens wat dui op 'n uiters negatiewe verband tussen die heidennasies en God (vgl. Bavinck, 1928:287). So word daar gepraat van "duisternis" onder die nasies (Jes. 60:2; Luk. 1:79; Ef. 4:18), van volslae "onkunde" (Hand. 17:30; Gal. 4:8; Ef. 4:18; 1 Tess. 4:5; 1 Pet. 1:14), van heidene wat blindelings na stom afgode meegevoer is (1 Kor.1 2:2), ja, van alles wat verwerplik en verfoeilik is (vgl. 1 Pet. 4:3-4); die prentjie wat Paulus in Romeine 1:29-32 van die ongelowiges skets, is allesbehalwe vleiend. Vir ons huidige debat is dit belangrik dat ook hiérdie (uiters negatiewe) gegewens behoorlik verreken word, dat ons nie selektief met die Skrifgegewens sal omgaan nie en dat ons daarom nie Romeine 1-2 as die enigste relevante gegewens in hierdie verband sal hanteer nie.10 Daarby is dit van die uiterste belang om in ons interpretasie van die relevante Skrifgegewens ook rekening te hou met die variërende kontekste van elkeen van hierdie tekste.

Ons vraagstelling word in 'n baie groot mate beheers deur die vraag na die verhouding tussen Woord en Gees. Die vraag is hier tersake of die gemiddelde gereformeerde (teoloog en lidmaat) in hierdie opsig nie meer Luthers as Calvyns dink nie. Hieroor kortliks die volgende. In die dogmatiek word soms (maar dan as sterk veralgemening) die volgende onderskeidings gehanteer (vgl. Berkouwer, 1966:40-82; Berkhof, 1990: 63; Jonker, 1981:50-58; Van Genderen \& Velema, 1992:688-697):

- Luther leer dat die Gees (slegs) deur die Woord werk (per verbum)

- Die Anabaptiste leer dat die Gees buite die Woord om werk (sine verbo)

- Calvyn leer dat die Gees met die Woord werk (cum verbo).

Hoewel hierdie tipering 'n oorvereenvoudiging is, bevat dit tog hierdie waarheidselement dat die gereformeerde tradisie, wat ook die werking "deur die Woord" ken (HK 25:65), tog sterker as die Lutherse tradisie die vryheid van die Gees gehandhaaf het (vgl. Jonker, 1981:57; 1994:3839). So was Calvyn van oordeel dat die Gees normaalweg deur die Woord werk, maar dat Hy in sy vrymag ook buite die Skrifgeworde Woord kan werk. In sy hantering van besware teen die kinderdoop wys Calvyn (Inst. 4.16.19) daarop dat die gehoor gewoonlik die beginsel van

10 Vgl. die konklusie van Versteeg (1985:46) in hierdie verband: "Voor de theorie van de natuurlijke godskennis zijn aan Romeinen 1 en 2 bij nader inzien geen bouwstenen te ontlenen. Wanneer in Romeinen 1:18-23 gesproken wordt over een kennen van God, wordt daarmee geen ander kennen bedoeld dan het kennen van God uit zijn heilshandelen in de geschiedenis van het volk Israël en van de zijnen. Door oog te hebben voor wat in Israël gebeurde konden ook de heidenen God leren kennen. Zij hebben zich evenwel altijd ... tegen de openbaring van God verzet." 
die geloof is (Rom. 10:9), maar dat die Here ook van uitsonderings kan gebruik maak en dan sê hy: "So het Hy [die Here] beslis verskillende maniere gebruik in die roeping van baie mense aan wie Hy innerlik deur die verligting van die Gees en sonder die tussenkoms van die prediking ware kennis oor Hom geskenk het." Die Gees maak van die Woord gebruik, maar nie op sodanige wyse dat Hy 'n slaaf van die Woord word nie.11

'n Laaste en belangrike vraag wat in hierdie verband genoem moet word, is die vraag of 'n standpunt wat uit die skeppingsopenbaring ook heilskennis aflei, nie noodwending tot die beëindiging van sendingwerk moet lei nie, of minstens die dringendheid van sending ernstig moet bevraagteken nie.

\section{M.A. Kruger: 'n poging om hom te verstaan: die toets van die vyf solismes}

Daar is reeds eerder in punt 1 kortliks verwys na enkele uitsprake van M.A. Kruger. Dit het tans nodig geword om in meer besonderhede aandag aan sy standpunt te bestee. Kruger het, veral op grond van sy studie van Romeine 1-2 (vgl. Kruger, 1985; 2000b) tot die konklusie gekom dat die skeppingsopenbaring voldoende kan wees om tot saligmakende kennis te kom. Vir ons doel kan dit nuttig wees om die standpunt van Kruger te ontvou, en tegelykertyd te toets aan die hand van die bekende vyf solismes van die Reformasie van die sestiende eeu. Op hierdie wyse sal ons kan vasstel of, en indien wel, in watter mate, Kruger hom van die Reformatoriese denke gedistansieer het. Het hy hom téén die Reformatoriese teologie gekeer of het hy vérder gegaan as die Reformasie?

\subsection{Soli Deo gloria? (Ja!)}

Volgens my oordeel bestaan daar algemene konsensus dat hierdie tema hier glad nie in gedrang - of selfs in diskussie - is nie. Uit die geskrifte van Kruger - asook uit persoonlike ervaring - kan daar geen twyfel bestaan dat die eer van God ook vir hom 'n sentrale teologiese tema uitmaak nie.

11 Volgens my waarneming dink die gemiddelde Gereformeerde predikant in Suid-Afrika meer Luthers as Calvyns oor die verhouding tussen die Woord en die Gees. 


\subsection{Sola gratia? (Ja!)}

Mens sou - met reg - die vraag kon stel of daar nog van "genade alleen" sprake kan wees indien die heilsnoodsaaklikheid van die spesifieke openbaring van Jesus Christus bevraagteken word.

As ek Kruger reg verstaan, wil hy volledig reg laat geskied aan die redding uit "genade alleen". So verwys hy byvoorbeeld krities na die natuurlike religie wat aan die mens die vermoë toeskryf om al denkend by God uit te kom (Kruger, 2000a:12). Die gevalle mens beskik nie oor die vermoë om vanuit homself by God uit te kom as dit hom nie uit genade deur God geskenk word nie. "It is not man's ability to come to God which brings salvation, but God's coming to man" (Kruger, 2000a:9).

\subsection{Sola fide? (Ja!)}

Ook in hierdie geval kan die vraag (tereg) gestel word of Kruger hom nie skuldig maak aan 'n werkgeregtigheid nie. Maar ook in hierdie geval verstaan ek hom so dat werkheiligheid volkome uitgesluit is en dat enige persoon slegs deur 'n ware geloof, dit wil sê "in full trust upon God" (Kruger, 2000a:13) gered kan word. Die outeur van hierdie geloof is niemand anders nie as die Heilige Gees (Kruger, 2000a:13). Die waarde wat Kruger aan die natuuropenbaring verleen, lei hom dus nie tot die punt dat hy die aard van die geloof (as vertroue) ontken nie.

\subsection{Solo Christo? (Ja, maar)}

Kom ons nou by die vraag na "Christus alleen", vermeerder die vrae uiteraard. Die vraag kan immers - weer eens tereg - gestel word of Kruger se benadering nie die uniekheid van die koms en werk van Christus aantas en daarmee die ganse evangelie op die spel plaas nie. Kan 'n mens ná die koms van Christus nog praat van 'n situasie asof $H y$ nooit werklik gekom het nie? Verkeer heidene in dieselfde situasie as Ou-Testamentiese gelowiges wat op die koms van die Messias gewag het? Dit dan om maar enkele van die vrae op te som.

Wat is Kruger se antwoord hierop? Hy reageer deur hom daarop te beroep dat die ware God wat Hom in die natuur openbaar, niemand anders kan wees nie as die drie-enige God, Vader, Seun en Heilige Gees. Die heiden wat in geloof op die Godsopenbaring in die natuur reageer, glo dus noodwendig ook in Christus. "The same Triune God, Father, Son and Holy Spirit, reveals himself by speaking in the creation, preservation and government of the universe ..." (Kruger, 2000a:6). 'n Oorgawe aan die God van die openbaring " is a submission to the Triune God and therefore not without Christ” (Kruger, 2000:9). 
Anders gesê :

lemand kan dus gered word as hy soos Abraham vertrou en glo selfs sonder dat hy die Naam van Jesus Christus ken of 'n omlynde belydenis van die drie-enige God het. Niemand word verlos sonder Christus nie (my kursivering - JHvW). Maar 'n vertrouende oorgawe aan God op grond van die openbaring 'apo ktiseos kosmou' is ook geloof in die drie-enige God, dus ook in Christus (Kruger, 1985:145).

Kruger kan dus nie gekritiseer word dat Christus vir die heilsproses onbelangrik sou wees nie, maar die vraag is wel tersake of sy argument in verband met die implisiete Christusprediking (volledig) opgaan, noudat die inkarnasie, die kruis en opstanding reeds plaasgevind het en openlik verkondig word. Selfs al sou toegegee word dat Kruger se standpunt nie die einde van alle sendingwerk impliseer nie, moet die vraag minstens gevra word of dit nie die dringendheid van alle sendingwerk in gedrang bring nie.

Heidene verkeer dus basies in dieselfde omstandighede as Israel ten tye van die Ou Testament, laasgenoemde vertrouend op die (koms van die) Messias aan die hand van die Skrifopenbaring (in die Ou Testament) en laasgenoemde vertrouend op die Messias aan die hand van die natuuropenbaring. Dieselfde vraagstelling as hierbo kom ook hier na vore.

Kruger (1983:378-380) wys die kritiese vraag in verband met die noodsaak van sending af. Die verkondiging van die evangelie van Christus, met sy veel helderder lig, bly steeds nodig. Net soos sending 'n passie was vir Paulus, wat so breed kon skryf oor die skeppingsopenbaring, net so bly sending ook vandag 'n onnalaatbare opdrag en roeping.

\subsection{Sola Scriptura? (Ja-nee)}

Uiteraard kan verwag word dat die grootste probleme by hierdie onderafdeling aangetref sal word. Die kritiek teen Kruger is duidelik. Sy standpunt loop uit op 'n oorwaardering van die natuuropenbaring en 'n onderwaardering van die Skrifopenbaring - in stryd met NGB art 2.

Sy weerwoord bevat die volgende aspekte:

- Hy wys daarop dat die openbaring van God (Woord van God) wyer as die Bybel gaan. Daarby moet verreken word dat dit in alle fasette van die Godsopenbaring gaan oor die openbaring van God aan die mens en dus nie oor die méns se natuurlike soeke na God nie en in hierdie verband speel die onderskeiding tussen revelatio naturalis (negatief) en religio naturalis (positief) 'n deurslaggewend 
rol. Die normatiwiteit van die Bybel (as "duideliker en meer volkome" openbaring) word erken.

Kruger wys daarop dat die leuse "die Skrif alleen" oorspronklik gebruik is in opposisie teen die Rooms-Katolieke tradisionalisme12, maar dat dit later (in die Westminsterse Konfessie, 1646) van betekenis verander het (geradikaliseer is) om op die onselfgenoegsaamheid van die natuuropenbaring te dui (Kruger, 2000a:7-8).

- Uiteraard speel die interpretasie van NGB 2 'n belangrike rol, byvoorbeeld reeds die sin: "Ons ken Hom deur twee middele". Wat beteken die woordjie "ken"? Volgens Kruger (2000a:4) beteken "ken" niks anders nie as "a knowledge of God which is sufficient as means of revelation to bring one to salvation in God".

- In NGB 2 is die interpretasie van die volgende sin ook belangrik: "Al die dinge is genoegsaam om mense te oortuig en hulle alle verontskuldiging te ontneem". Die vraag is: wat is die reikwydte van die woord "oortuig"? Beteken dit "oortuig van sonde" of ook "oortuig van verlossing"? Kruger (2000a:4) is van mening dat "oortuig" ook verstaan moet word as "to convince so that one can come to saving faith" (so ook Kruger, 1983:372).

Gevolglik is Kruger van mening dat sy beskouing nie in stryd is met die NGB en DLR nie. Ook waar hierdie belydenisskrifte handel oor die klein oorblyfsels van die lig van die natuur, gaan dit nie oor die Godsopenbaring van Romeine 1 nie, maar oor die menslike vermoë, die krag van die rede van die mens, sonder die krag van die Heilige Gees. "Dit gaan oor die sogenaamde vrye wil van die mens om die openbaring reg te kan verwerk om tot ware kennis te kom. Dit gaan oor die mate van oorgeblewe ongeskondenheid van die menslike rede" (Kruger 1983:372). Hier is egter geen sprake van ongenoegsaamheid van die openbaring buite die Skrif om nie.

- Kruger (2000a:13) doen ook 'n sterk beroep op die werk van die Heilige Gees, wat werk waar en soos Hy wil:

A dangerous view within Reformed theology is that the Holy Spirit's work of regeneration is limited to working through Scriptures. Although this is certainly the highest way, or the brightest light, the Holy Spirit can never be limited to working through the Scriptures only."

Hy oordeel dat dit "die Heilige Gees is wat die verskil maak tussen onderdrukking van die openbaring of ontvangs daarvan"; die Heilige Gees het die krag om iemand tot saligmakende kennis te lei ook voordat

Vir dieselfde standpunt, vgl. Scheffler (1987:71). 
die Skrif bestaan het (Kruger, 1983:374). Hy verwys in hierdie verband ook graag na die figuur van Melgisedek (Kruger, 1985:146) aan wie die Godsopenbaring anders as by Abraham plaasgevind het.

In sy kritiek op Bavinck wys hy daarop dat die Skrifopenbaring wel normatief is, maar nie eksklusief nie;13 dit relativeer en elimineer nie die Godsopenbaring van Romeine 1 nie (Kruger, 1983:369).

\subsection{Voorlopige gevolgtrekking en voortgaande diskussie}

Eerstens word 'n aantal waarderende opmerkings gemaak, opgevolg deur 'n aantal kritiese vrae.

- Dit moet by Kruger waardeer word dat hy 'n ernstige poging aangewend het om die Bybelse leer oor God suiwer te hou, naamlik dat God nie uitgebeeld word as genadeloos, liefdeloos en onregverdig nie (vgl. byvoorbeeld Eks. 34:6; Neh. 9:17; Ps. 86:15; 103:8; 145:8; Joël 2:13; Jona 4:2). Dít, meen ek, is die diepste intensie van die outeur, wat deurlopend gehonoreer moet word. Onlosmaaklik hiermee verbind, gaan 'n besondere bewoënheid oor die ewige lot van mense wat nooit die evangelie gehoor het nie. Uiteraard is hiermee nie alle vrae opgelos nie aangesien die geheim van God se uitverkiesing (waarom net sommige uitverkies word) uiteindelik nie rasioneel deursigtig te maak is nie.

- Verder moet by hom waardeer word dat hy hom welbewus binne die Reformatoriese tradisie posisioneer, met positiewe waardering vir die solismes van die Reformasie; voorts dat hy ook afstand wil doen van allerlei skolastieke elemente wat hierdie tradisie asook die gereformeerde dogmatiek dikwels ontsier.

- Waardering moet ook uitgespreek word vir die klem wat gelê word op die belangrikheid van deeglike eksegese - selfs al sou die resultate van daardie eksegese 'n tradisie van 2000 jaar bevraagteken.

- Verder moet waardeer word dat Kruger nuwe besinning losgemaak het oor die vraag na die reikwydte van die skeppingsopenbaring, die twee middele van Godskennis, en die betekenis wat hierdie openbaring vir die dogmatiek (verlossing) en die etiek (heiliging) sou kon inhou.

Daar moet egter ook 'n aantal kritiese vrae gestel word.

- Kruger se Skrifberoep is hoofsaaklik op Romeine gebaseer. Dit moet as 'n leemte aangemerk word dat hy nie alle relevante Skrifgegewens 
(ook buite Romeine) in sy ondersoek (en gevolgtrekkings) betrek het nie. Sy benadering volg ook 'n interessante sirkelredenering: Dit is juis op grond van die uniekheid van die Skrifopenbaring dat hy konkludeer tot die genoegsaamheid van die skeppingsopenbaring.

- Kruger is van mening dat hy nie teen die Konfessie ingaan nie, maar daarvan juis 'n outentieke vertolking verskaf. Daarby is hy van oordeel dat sy standpunt op die Skrif gebaseer is. Hoewel 'n mens sou kon redeneer dat Kruger nie téén die Konfessie ingaan nie, gaan hy vir my aanvoeling vérder as die Konfessie. Hoe verantwoordbaar hierdie standpunt is, is juis die punt van diskussie. Die vraag wat beantwoord moet word, is: het ons hier te doen met 'n saak van libertas prophetandi? Kruger se siening van die gebruik van die konsep "oortuig" in NGB 2 (oortuiging óók "tot verlossing"), kan nie uit die NGB self afgelei word nie en kan ook moeilik vanuit die teologie van Calvyn - sy teologie as geheel - gesubstansieer word.

- Kruger se weergawe van Calvyn bring die beswaar na vore dat hy slegs konsentreer op Calvyn se openbaringsleer en nie ander belangrike aspekte van Calvyn se teologie, soos sy sondeleer, mensleer, Christologie en Pneumatologie, ook in berekening bring nie. Calvyn se teologiese oeuvre vorm 'n ondeelbare geheel, en wie een aspek daarvan wil verstaan of vertolk, moet noodwendig die geheel verdiskonteer.

- As dit alreeds 'n groot vraag is watter betekenis die skeppingsopenbaring vir die dogmatiek inhou, is dit 'n byna ondraaglike vraag om te vra hoeveel waarde dit vir die etiek sou kon inhou. Hoe ver kan gevorder word met 'n louter skeppingsetiek met sy skeppingsordeninge, wat al spoedig in 'n volksetiek van apartheid kan ontaard al weet ek dat Kruger teen laasgenoemde kritiek gehad het. In 'n suiwer skeppingsetiek-benadering het ek byvoorbeeld mense ter ondersteuning van die ideologie van apartheid, soos volg hoor redeneer: diere (bv. buffels en koedoes) vermeng nie en dus moet mense ook nie vermeng nie, maar apart bly!

By verskil van mening, moet die vraag uiteindelik beantwoord word of ons hier te doen het met 'n libertas prophetandi. Daar is diegene wat van mening is dat die standpunt van Kruger téén die gereformeerde Belydenisskrifte ingaan én daar is ander (soos ekself) wat van oordeel is dat sy standpunt vérder gaan as die Konfessie. Die vraag is: behoort sy standpunt binne die gereformeerde tradisie getolereer te word of tas dit die hart van evangelie aan sodat slegs 'n radikale nee uitgespreek behoort te word? 
Dat daar ook binne die gereformeerde tradisie sprake kan wees van 'n bepaalde leerstellige ruimte, sonder om in konfessionele indifferentisme te verval, kan gesien word aan die klassieke voorbeeld van die chiliasme (diegene wat op grond van Openbaring 20 'n letterlike duisendjarige vrederyk aanvaar) (vir 'n oorsig, vgl. Wentsel, 1998:433-449). Hoewel daar in die Vroeë Kerk belangrike voorstanders van die chiliasme was, soos Irenaeus en Tertullianus, is dit sedert Origines en Augustinus (civ Dei, 20:7-9) en latere groot teoloë soos Tomas van Aquino, Luther, Calvyn, Bavinck en Berkouwer afgewys. Calvyn (Inst, 3.25.5) het dit selfs 'n "kinderagtige verdigsel" genoem. Ook in die Confessio Augustana en die Confessio Helvetica posterior is dit verwerp. Tog was die GKSA bereid om die Gereformeerde Kerke onder die Kruis, waarin hierdie standpunt redelik algemeen voorgekom het, in 1914 in die kerkverband van die GKSA op te neem (vgl. Jooste, 1958:220-245; D'Assonville, 1999:341-362). Daar is tereg geoordeel dat hierdie gereformeerde Christene met hulle bepaalde standpunt oor die vrederyk nie die hart van die evangelie van Christus aangetas het nie en dat in hierdie geval sprake behoort te wees van 'n libertas prophetandi.14

Ons weet dat ook Calvyn (Inst. 4.1.12) tussen fundamentele en middelmatige sake onderskei het en dat hy hierdie onderskeiding ook op leerstellige sake van toepassing gemaak het; solank die hoofpunte van die Christelike leer gehandhaaf bly, mag daar nie 'n kerkskeuring plaasvind nie. Calvyn wil hiermee nie 'n lansie breek vir leervryheid nie, maar 'n pleidooi lewer vir kerkeenheid wat nie deur verskil oor middelmatige dinge versteur behoort te word nie (Inst. 4.1.12; vgl. 4.2.1).

Sou dieselfde gesê kon word van die standpunt van Kruger oor die reikwydte van die skeppingsopenbaring - libertas prophetandi? Alhoewel ek bepaalde voorbehoude en kritiek het ten opsigte van Kruger se standpunt, kan myns insiens gekonkludeer word dat in sy siening die vyf solismes van die Reformasie grotendeels gehandhaaf word.

\section{Samevattende opmerkings}

- Hoewel die dogmageskiedenis en dogmatiek belangrike boustene kan lewer tot 'n bevredigende oplossing van ons vraagstelling, is dit ten diepste 'n eksegetiese vraag.

- In ons Skrifverstaan behoort nie net op enkele Skrifdele gekonsentreer te word nie (bv. Rom. 1-2), maar moet alle relevante dele (ook

14 Dit is insiggewend dat Du Toit (Totius) (1977) geen preek oor Openbaring 20 gemaak het nie. Sowel Totius se vader, S.J. du Toit, as sy broer, C.W.M. du Toit (s.j.:373-421) was chiliaste. 
buite Romeine) betrek word. Die Reformatore het nie net die sola Scriptura beklemtoon nie maar ook die tota Scriptura.

- Die gereformeerde - en selfs breë Christelike - tradisie is, met bepaalde nuanses, redelik eenstemmig in sy siening van die inhoud en betekenis van die natuuropenbaring (soos uiteengesit) (behalwe natuurlik vir Barth c.s.).

- Die uniekheid van die heilsopenbaring in Christus staan vas (Joh. 14:6; Hand. 4:12). Maar uniekheid beteken nie noodwendig eksklusiwiteit nie.

- Dat God deur sy Gees ook buite die Skrifopenbaring om werk, is uit die Skrifgegewens self duidelik. Oor die hoé daarvan (die inhoud en resultaat) kan ons vandag moeilik 'n oordeel uitspreek.

- Die gereformeerde teologie werk met gegewens wat God geopenbaar het. Dit spreek dus geen oordeel uit oor mense wat nie/nooit die evangelie van Christus gehoor of kon gehoor het nie. Dit is 'n oordeel wat aan God alleen oorgelaat word. Wat God deur sy Gees in sy vrymag kan doen, is nie vir menslike oordeel toeganklik nie. 15

\section{Bibliografie}

ACTA GKSA. 2000. Gereformeerde Kerke in Suid-Afrika: Handelinge van die seween veertigste nasionale sinode te Potchefstroom. Potchefstroom : Administratiewe Buro.

AURELIUS AUGUSTINUS. De stad van God (afgekort as civ Del). Baarn : Ambo. (Vert. G. Wijdeveld.) 1983.

BAKHUIZEN VAN DEN BRINK, J.J. 1940. De Nederlandsche Belijdenisgeschriften: Vergelijkende teksten. Amsterdam : Holland.

BARTH, K. 1960a. Die Kirchliche Dogmatik 1/2. Zürich : Evangelischer Verlag.

BARTH, K. 1960b. Die Kirchliche Dogmatik 4/1. Zürich : EVZ-Verlag.

BAVINCK, H. 1928. Gereformeerde Dogmatiek 1. Kampen : Kok.

BAVINCK, H. 1930. Gereformeerde Dogmatiek 4. Kampen : Kok.

BAVINCK, J.H. 1949. Religieus besef en Christelijk geloof. Kok : Kampen.

BAVINCK, J.H. 1954. Inleiding in de zendingswetenschap. Kampen : Kok.

BEKER, E.J. \& HASSELAAR, J.M. 1978. Wegen en kruispunten in de dogmatiek. Deel 1. Kampen : Kok.

BERKHOF, H. 1990. Christelijk geloof: Een inleiding tot de geloofsleer. Nijkerk : Callenbach.

BERKOUWER, G.C. 1951. De algemene openbaring. Kampen : Kok.

15 "Met de Schrift in de hand kunnen wij, zoowel in betrekking tot de zaligheid der Heidenen als tot die der vroegstervende kinderen, niet verder komen, dan dat wij van een beslist en stellig oordeel in positieven of negatieven zin ons onthouden" (Bavinck, 1930:708). 
BERKOUWER, G.C. 1957. De mens het beeld Gods. Kampen : Kok.

BERKOUWER, G.C. 1966. De Heilige Schrift I. Kampen : Kok.

CALVYN, J. 1984, 1986. Institusie van die Christelike godsdiens 1559 (1/3). Potchefstroom : CJBF. (Vert. H.W. Simpson.)

D'ASSONVILLE, V.E. 1999. SJ du Toit van die Paarl (1847-1911). Weltevredenpark : Marnix.

DU PREEZ, J. 2000. Is daar tóg ander paaie na God? Die Kerkbode: 10, April 7.

DU TOIT, C.W.M. s.j. Toekomstige wêreldgebeure in die lig van die Skrif: 'n Verklaring van die boek Openbaring, vir ons tyd bewerk. Roodepoort : VGKF.

DU TOIT, J.D. 1977. Totius Versamelde Werke 5. Kaapstad : Tafelberg. (Red. H. Venter.)

DEKKER, W. 1996. Niemand los van God - over de algemene openbaring. (In Van den Brink, G et al., reds. Gegrond geloof: Kernpunten uit de geloofsleer in bijbels, historisch en belijdend perspectief. Zoetermeer : Boekencentrum. p. 93123.)

HEYNS. J.A. 1978. Dogmatiek. Pretoria : NG Kerkboekhandel.

HEYNS, J.A. 1988. Inleiding tot die dogmatiek. Halfway House : NG Kerkboekhandel.

INST.

kyk Calvyn, J. (1984, 1986)

JONKER, W.D. 1981. Die Gees van Christus. Pretoria : NG Kerkboekhandel.

JONKER, W.D. 1994. Bevrydende waarheid: Die karakter van die gereformeerde belydenis. Wellington : Hugenote-Uitgewers.

JOOSTE, J.P. 1958. Die geskiedenis van die Gereformeerde Kerk in Suid-Afrika 1859-1959. Potchefstroom : Admin Buro.

KRUGER, M.A. 1983. Openbaring, geloof en geregtigheid. 'n Eksegetiese ondersoek van Romeine 1-4. Pretoria : UP. (Proefskrif.)

KRUGER, M.A. 1985. Romeine 1-4: 'n Ander eksegese. Hervormde Teologiese Studies, 41(1):130-147.

KRUGER, M.A. 1988. Naby jou is die Woord! Romeine 10:8. (In Coetzee, J.C., red. Koninkryk, Gees en Woord: Huldigingsbundel aangebied aan prof. dr. Lambertus Floor. Pretoria : NG Kerkboekhandel. p. 81-97.)

KRUGER, M.A. 1993. 'n Weg uit die oorheersing van die histories-kritiese metode, fundamentalisme en genitiefteologieë. In die Skriflig, 27(4): 583-602.

KRUGER, M.A. 2000a. The kingdom of God and those who have not heard the contents of Scripture. (Ongepubliseerde voordrag tydens Calvyn-kongres 2000 te Potchefstroom.)

KRUGER, M.A. 2000b. Commentary on Romans. Clubview : Benedic Books.

KRUGER, M.A. 2002. Brief aan Kuratorium van die GKSA. (20 Februarie) (Ongepubliseer.)

MALAN, F. 1994. Boekbeskouing. B. van der Walt, God praat met ons (1993).

Potchefstroom : IRS. Ned Geref Teologiese Tydskrif, 35(1):152-154.

NOTULE KURATORIUM GKSA, 17-18 Junie 1998.

NOTULE KURATORIUM GKSA, 13-14 November 2001.

NOTULE NASIONALE SINODE GKSA, 2003. (Ongepubliseer.)

PANNENBERG, W. 1988. Systematic Theology I. Edinburgh : Clark.

PANNENBERG, W. 1993. Towards a theology of nature. Louisville/Ky : John Knox Press.

POLMAN, A.D.R. z.j. Onze Nederlandsche Geloofsbelijdenis: Verklaard uit het verleden, geconfronteerd met het heden. Franeker : Wever. 
POLMAN, A.D.R. 1949. De openbaring Gods. (In Berkouwer, G.C. \& Toornvliet, G. Het dogma der kerk. Groningen : Haan. p. 80-110.)

SCHEFFLER, E.H. 1987. Die gebruik van die Nuwe Testament in die Nederlandse Geloofsbelydenis. (In Bosman, H.L. et al. Die Nederlandse Geloofsbelydenis Ontstaan, Skrifgebruik en gebruik. Pretoria : UP. p. 70-88.)

SPYKMAN. G. 1992. Reformational theology: A new paradigm for doing dogmatics. Grand Rapids : Eerdmans.

STOKER, H.G. 1970. Oorsprong en rigting II. Kaapstad : Tafelberg.

THOMAS VAN AQUINO: St Thomas van Aquino: Summa Theologiae. A concise translation. London : Eyre \& Spottiswoode. (T McDermott, ed.). 1989.

VAN DER WALT, B.J. 1989. Oor gode en mense: Inleiding tot 'n Christelike godsdiensfilosofie. Potchefstroom : $\mathrm{PU}$ vir $\mathrm{CHO}$.

VAN DER WALT, B.J. 1992. Venster op die werklikheid: 'n Reformatoriese lewensvisie-filosofie-wetenskap. Potchefstroom : $\mathrm{PU}$ vir $\mathrm{CHO}$.

VAN DER WALT, B.J. 1994. The liberating message: A Christian worldview for Africa. Potchefstroom : PU for CHE/IRS.

VAN DER WALT, B.J. 1995. Die hand in eie boesem: 'n Besinning oor Afrikaneridentiteit. Potchefstroom : $\mathrm{PU}$ vir $\mathrm{CHO}$.

VAN DER WALT, B.J. 1999. Visie op die werklikheid: Die bevrydende krag van 'n Christelike lewensbeskouing en filosofie. Potchefstroom : PU vir CHO.

VAN GENDEREN, J. \& VELEMA, W.H. 1992. Beknopte Gereformeerde Dogmatiek. Kampen : Kok.

VAN RULER, A.A. 1978. Verwachting en voltooiing. Nijkerk : Callenbach.

VAN WYK, D.J.C. 1973. Die probleem van die algemene openbaring, histories nagegaan en prinsipieel getoets. Pretoria : UP. (Proefskrif.)

VAN WYK, J.H. 1993. Homo Dei: 'n Prinsipiële besinning oor enkele mensbeskouings, waaronder dié van Calvyn. In die Skriflig, Supplementum 1.

VAN WYK, J.H. 2001. Etiek en eksistensie in koninkryksperspektief. Potchefstroom : PTP.

VERSTEEG, J.P. 1985. Natuurlijke Godskennis in Romeinen 1 en 2. (In Van Leeuwen, C. et al. Met het Woord in de tijd: Een bundel artikelen rondom het thema "evangelisatie en cultuur" uitgegeven ter gelegenheid van het 50 -jarig bestaan van de Hervormde Bond voor Inwendige Zending (IZB) te Amersfoort. 's-Gravenhage : Boekencentrum. p. 27-48.)

VISSER, P.J. 1999. Bemoeienis en getuigenis: Het leven en de missionaire theologie van Johan H. Bavinck (1895-1964). Zoetermeer : Boekencentrum.

WENTSEL, B. 1982. De openbaring, het verbond en de apriori's. Dogmatiek 2. Kampen : Kok.

WENTSEL, B. 1987. God en mens verzoend: Godsleer, mensleer en zondeleer. Kampen : Kok.

WENTSEL, B. 1998. De Heilige Geest, de kerk en de laatste dingen: De genademiddelen, het gemenebest en het eschaton. Dogmatiek 4c. Kampen : Kok.

WIELENGA, B. 1998. Verbond en zending: Een verbondsmatige benadering van zending. Kampen : Mondiss. 


\section{Kernbegrippe:}

algemene openbaring insufficientia

Kruger, M.A.

natuuropenbaring

skeppingsopenbaring

\section{Key concepts:}

creational revelation

general revelation

insufficientia

Kruger, M.A.

natural revelation 
